\title{
Diagnosing Alzheimer's disease: A systematic review of economic evaluations
}

Citation for published version (APA):

Handels, R. L. H., Wolfs, C. A. G., Aalten, P., Joore, M., Verhey, F. R. J., \& Severens, J. L. (2014).

Diagnosing Alzheimer's disease: A systematic review of economic evaluations. Alzheimer's \& Dementia, 10(2), 225-237. https://doi.org/10.1016/j.jalz.2013.02.005

Document status and date:

Published: 01/03/2014

DOI:

10.1016/j.jalz.2013.02.005

Document Version:

Accepted author manuscript (Peer reviewed / editorial board version)

Document license:

Unspecified

\section{Please check the document version of this publication:}

- A submitted manuscript is the version of the article upon submission and before peer-review. There can be important differences between the submitted version and the official published version of record.

People interested in the research are advised to contact the author for the final version of the publication, or visit the DOI to the publisher's website.

- The final author version and the galley proof are versions of the publication after peer review.

- The final published version features the final layout of the paper including the volume, issue and page numbers.

Link to publication

\footnotetext{
General rights rights.

- You may freely distribute the URL identifying the publication in the public portal. please follow below link for the End User Agreement:

www.umlib.nl/taverne-license

Take down policy

If you believe that this document breaches copyright please contact us at:

repository@maastrichtuniversity.nl

providing details and we will investigate your claim.
}

Copyright and moral rights for the publications made accessible in the public portal are retained by the authors and/or other copyright owners and it is a condition of accessing publications that users recognise and abide by the legal requirements associated with these

- Users may download and print one copy of any publication from the public portal for the purpose of private study or research.

- You may not further distribute the material or use it for any profit-making activity or commercial gain

If the publication is distributed under the terms of Article $25 \mathrm{fa}$ of the Dutch Copyright Act, indicated by the "Taverne" license above, 


\section{Diagnosing AlZheimer's DiSEASE: A SYSTEMATIC REVIEW OF ECONOMIC EVALUATIONS}

Handels RL, Wolfs CA, Aalten P, Joore MA, Verhey FR, Severens JL.

Published in Alzheimers Dement. 2014 Mar;10(2):225-37

Reprinted from Alzheimer's \& Dementia 2014 Mar;10(2):225-37 Handels RL, Wolfs CA, Aalten P, Joore MA, Verhey FR, Severens JL. Diagnosing Alzheimer's disease: A systematic review of economic evaluations. Copyright (2014), with permission from Elsevier 


\section{Abstract}

Background: The objective of this study is to systematically review the literature on economic evaluations of interventions for the early diagnosis of Alzheimer's disease (AD) and related disorders and to describe their general and methodological characteristics. We focused on the diagnostic aspects of the decision models to assess the applicability of existing decision models for the evaluation of the recently revised diagnostic research criteria for AD.

Methods: PubMed and the National Institute for Health Research Economic Evaluation database were searched for English-language publications related to economic evaluations on diagnostic technologies. Trial-based economic evaluations were assessed using the Consensus on Health Economic Criteria list. Modeling studies were assessed using the framework for quality assessment of decision-analytic models.

Results: The search retrieved 2109 items, from which eight decision-analytic modeling studies and one trial-based economic evaluation met all eligibility criteria.

Conclusions: Diversity among the study objective and characteristics was considerable and, despite considerable methodological quality, several flaws were indicated. Recommendations were focused on diagnostic aspects and the applicability of existing models for the evaluation of recently revised diagnostic research criteria for AD. 


\section{INTRODUCTION}

Alzheimer's disease (AD) and other dementing disorders are common in the elderly, with a worldwide prevalence estimated in 2010 at 35.6 million, which will increase to 115.4 million in 2050. AD has a substantial impact on the person who suffers from the disease, his or her family, and society [1] and [2]. The total worldwide cost of $A D$ and other dementing disorders was estimated at $\$ 604$ billion in 2010 [3].

Earlier diagnosis and early intervention are considered important mechanisms to manage the worldwide impact of the disease. Early diagnosis can be described as a "timely" recognition of mild dementia in response to a patient's complaints to ensure that disabled individuals receive the necessary support and care or as the "symptomatic predementia" diagnosis when cognition is impaired but functioning not yet affected (typically referred to as mild cognitive impairment) [4].

Until recently, the diagnosis of AD was largely based on clinical judgment using the NINCDS-ADRDA criteria [5]. These criteria were recently revised [6], [7] and [8] to enhance diagnostic accuracy and enable an early diagnosis even when only very mild clinical symptoms are present. Biomarkers in cerebrospinal fluid (CSF), positron emission tomography (PET), magnetic resonance imaging (MRI), and photon emission tomography (SPECT) are attributed a more prominent role in the new diagnostic research criteria. However, validation of these research criteria is needed before the role of new biomarkers can be adopted in clinical practice [9].

The ultimate goal of diagnostic testing is to guide disease management to improve patient outcomes and patient well-being. Tests that lack this potential are considered obsolete [10] and [11]. Furthermore, because health-care resources are scarce and must be allocated efficiently, decision-makers require evidence of the cost-effectiveness of diagnostic tests before adoption in clinical practice. Such evidence can be generated by decision-analytic models which are defined as a set of mathematical relationships that form a structure reflecting the natural progression of a disease. By simulating patient cohorts, these models enable the estimation of the likelihood of each consequence and its corresponding costs and effects [12] and [13]. Trial-based economic evaluations, in which costs and health-care outcomes are measured during clinical trials, can also provide evidence of cost-effectiveness.

Decision-analytic models of AD have been reviewed extensively by Cohen et al [14]. However, this review only included models that project disease progression, excluding possible relevant evidence on the evaluation of diagnostic techniques. Furthermore, the applicability of existing decision models to evaluate the recently revised research criteria has not been elaborated. This raises the urgent need for a review of economic evaluations of diagnostic interventions for AD.

The objective of this study was to systematically review the literature on economic evaluations of interventions for the early diagnosis of $A D$ and related disorders and to describe their general and methodological characteristics. Using these results, recommendations for future studies were focused on the diagnostic aspects of the decision models to assess the applicability of existing decision models for the evaluation of the recently revised diagnostic research criteria for AD. 


\section{METHODS}

\section{Search strategy}

A systematic literature review was performed to identify economic evaluations of diagnostic interventions for AD or related dementias. The following eligibility criteria were applied:

1. The study should focus on a population, either an empirical (primary data) or a theoretical (model), which is suffering from or suspected of suffering from AD or related disorders (vascular dementia, dementia with Lewy bodies, and frontotemporal dementia). The population should consist of previously undiagnosed individuals. Studies of neurodegenerative disorders were excluded (e.g., Parkinson's, Huntington's disease, or depression).

2. The population reflects humans, 55 years of age or older.

3. The intervention is a diagnostic technology, tool, questionnaire, process, procedure, or protocol used for a timely or symptomatic predementia diagnosis of $A D$ or related dementias in a clinical setting. Screening tools and risk, severity, or progression analyses were excluded (screening tools such as the Mini-Mental State Examination [MMSE] or DNA risk assessment).

4. The study reports primary patient and/or cost data or uses a mathematical model that is based on such data. Reviews, case studies, and publications that merely describe methodological issues were excluded.

5. The study is an economic evaluation: either a cost-consequence [15] analysis or a full economic evaluation (cost-effectiveness, cost-utility, or cost-benefit analyses). Partial economic evaluations, which do not include a comparison between different strategies or do not analyze both costs and consequences [16], were excluded.

PubMed and the National Institute for Health Research Economic Evaluation Database databases [17] and [18] were searched through March 2011. Medical subject headings and free text words on dementia, diagnosis, and economic evaluation were used to identify relevant English-language articles with an available abstract (see Appendix 1 for the full search query).

Two reviewers (R.H. and C.W.) independently assessed titles. A title was excluded if both reviewers agreed that it explicitly met one of the exclusion criteria. The same reviewers independently assessed abstracts of the remaining titles. An abstract was excluded if either reviewer considered that it did not meet all five inclusion and exclusion criteria. Dissimilarities in the reviewers' assessments were resolved by discussion. The full article was assessed if the remaining abstracts had dissimilarities that could not be otherwise resolved. If an article was not accessible, the author was contacted to request a copy of the original publication. A third reviewer (J.S.) resolved the remaining differences in the reviewer's assessments; this third reviewer made the final decision as to whether the article would be included. See Appendix 2 for an overview of the study selection process. 


\section{Analyses}

General study characteristics of all of the included articles are described in Table 1. For modeling studies, the model type was scored separately for the diagnostic and treatment part of the model. A Markov model is characterized by mutually exclusive disease states that represent the possible consequences of the options under evaluation. Disease progression is reflected by the transition of a patient's disease states over discrete time periods [12]. We used the term "state-independent" for mathematical models that apply a fixed time cycle similar to a Markov model but reflect the disease progression on a continuous scale and not by mutually exclusive disease states, such as the MMSE categories mild AD (MMSE 21-26), moderate AD (MMSE 14-20), moderately severe AD (MMSE 10-14), and severe AD (MMSE <10). If the treatment was only summarized in one or more fixed outcome values and was not represented by a mathematical model, it was scored as "static". Buxton et al [19] described five different roles of modeling in an economic evaluation that we used to classify all of the modeling studies: extrapolating beyond data observed in trial, linking the intermediate (clinical) endpoints to final outcomes, generalizing to other settings, synthesizing head-to-head comparisons where relevant trials do not exist, and informing decisions in the absence of hard data.

Methodological characteristics of the trial-based economic evaluations were assessed using the Consensus on Health Economic Criteria (CHEC) list [20] (see Table 2). Methodological characteristics of the modeling studies were assessed using the framework for quality assessment of decisionanalytic models [21] and [22] (see Table 3), which includes three key themes: structure, data, and consistency. Questions S3.2, S3.3, and S8 required expert knowledge in the field of AD and were clarified by a psychiatrist (F.V.). Furthermore, the framework is most likely intended for treatment interventions, although diagnostic interventions are the focus of this review and required adjustment of the items D2b1 and D2b2 that are described in Table 3. Two reviewers (C.W. and R.H.) independently performed analyses. In one case, one of the reviewers was the author of the paper being assessed; therefore, this reviewer was replaced by another reviewer (P.A.) to ensure objectivity. Dissimilarities in scoring were resolved by discussion. If discussion was not successful, a third reviewer (J.S.) determined the final score. Both of the checklist questions were answered with "yes" if both reviewers agreed that the study paid sufficient attention to an item, "no" if the item was not fulfilled or if insufficient information was available to assess the item, or "N/A" (not applicable) if the question was either not applicable to the study or if it referred to a previous question scored as "no". A summary score for each article was not applied because this quantitative scoring system was not considered to be sufficiently reliable and valid as a means of quality assessment. Therefore, a qualitative summary is provided to better distinguish major from minor methodologic flaws.

\section{RESULTS}

The search retrieved 2109 titles, of which 90 did not have an abstract available, 84 were duplicates, and an additional 180 were not in English. From the remaining 1755 titles, 936 were excluded based on the exclusion criteria. Of the remaining 819 titles, 735 were excluded after reading the abstracts, leaving 84 articles for assessment by R.H. and C.W. After reading the full articles, they excluded 75 articles on the basis of the exclusion criteria, of which 2 were assessed by the third reviewer (J.S.) because a decision could not be made through discussion between R.H. and C.W. Thus, a total of 
nine studies [23], [24], [25], [26], [27], [28], [29], [30] and [31] were included in the review. Fig. 1 displays a flowchart of the inclusion and exclusion process. Three articles [24], [25] and [26] analyzed a combination of two models of which the treatment part was published in a different article [32] and [33]. To fully evaluate the model, this publication was also included for assessment. Furthermore, the economic evaluation in two articles [25] and [26] was based on the same model and a similar situation applies to references 27 and 28 . If the articles referred to one another the information from the referenced article was also used to assess the article for this review.

\section{Figure 1: Flowchart of the inclusion process of the search results.}

\begin{tabular}{|l|l|} 
Literature search \\
PubMed and NHS EED with free \\
text words and MeSH headings
\end{tabular}

Table 1 provides an overview of the study characteristics. The studies can be divided into two categories on the basis of their objective. The first consists of three studies evaluating early diagnoses, which are strategies aimed at preventing underdiagnosis (i.e., timely recognition of patients suffering from dementia) to bring forward treatment. Although gained treatment effects in patients who would otherwise be undiagnosed were evaluated, the impact of an incorrect diagnosis (i.e., a false positive or false negative test outcome) was not included [23], [24] and [30]. The second category consists of six studies evaluating a specific diagnostic test or imaging strategy. Except for the trial-based study, a disease progression model was applied to describe costs and effects of true- and false-positive and -negative diagnostic pathways [25], [26], [27], [28], [29] and [31].

Diversity among the study characteristics was considerable on several items. Strategies under evaluation varied from specific imaging techniques to multidisciplinary assessments. Population ranged from non-demented patients with early symptoms to moderate dementia evaluated in 
various care settings. The time horizon ranged from 1 year to lifetime. At last, study outcomes and conclusions on the adoption of the intervention under evaluation in clinical practice differed between the studies. 
Table 1: General study characteristics

\begin{tabular}{|c|c|c|c|c|}
\hline Author & Banerjee et al. [23] & Getsios et al.[24]* & McMahon et al.[25]† & McMahon et al.[26]† \\
\hline Publication year & 2009 & 2012 & 2000 & 2003 \\
\hline Country & UK & UK & US & US \\
\hline Objective & $\begin{array}{l}\text { Analyze the costs and } \\
\text { benefits of commissioning } \\
\text { memory services for early } \\
\text { diagnosis and } \\
\text { intervention for dementia }\end{array}$ & $\begin{array}{l}\text { Evaluate the cost- } \\
\text { effectiveness of early } \\
\text { assessment and } \\
\text { treatment with AD with } \\
\text { Donepezil }\end{array}$ & $\begin{array}{l}\text { Evaluate the cost- } \\
\text { effectiveness of } \\
\text { functional neuroimaging }\end{array}$ & $\begin{array}{l}\text { Evaluate the cost- } \\
\text { effectiveness of PET in the } \\
\text { diagnosis of } A D\end{array}$ \\
\hline Study type & Modeling & Modeling & Modeling & Modeling \\
\hline Diagnostic modelł & Static & discrete event simulation & Decision-tree & $\begin{array}{l}\text { Decision-tree (based upon } \\
\text { model McMahon et.al.) }\end{array}$ \\
\hline Treatment model & Mathematical model & discrete event simulation & Markov model & Markov model \\
\hline Role of modeling§ & $\begin{array}{l}\text { Informing decisions in the } \\
\text { absence of hard data }\end{array}$ & $\begin{array}{l}\text { Informing decisions in the } \\
\text { absence of hard data }\end{array}$ & $\begin{array}{l}\text { Synthesizing head-to- } \\
\text { head comparisons where } \\
\text { relevant trials do not exist }\end{array}$ & $\begin{array}{l}\text { Synthesizing head-to- } \\
\text { head comparisons where } \\
\text { relevant trials do not exist }\end{array}$ \\
\hline Base case situation & Current practice & $\begin{array}{l}\text { Early assessment for AD } \\
\text { and treatment with } \\
\text { Donepezil }\end{array}$ & Standard examination & Standard examination \\
\hline Comparative strategies & $\begin{array}{l}\text { A multi-disciplinary and } \\
\text { interagency team to } \\
\text { generate early diagnosis }\end{array}$ & $\begin{array}{l}\text { (1) Treatment without } \\
\text { early assessment; (2) No } \\
\text { early assessment and no } \\
\text { treatment }\end{array}$ & $\begin{array}{l}\text { (1) MRI plus DSC MRI; (2) } \\
\text { Visual SPECT; (3) } \\
\text { Computed SPECT (all } \\
\text { added to standard } \\
\text { examination) }\end{array}$ & $\begin{array}{l}\text { (1) DSC MRI; (2) FDG PET; } \\
\text { (3) Computed SPECT (all } \\
\text { added to standard } \\
\text { examination) }\end{array}$ \\
\hline $\begin{array}{l}\text { Impact of diagnostic test } \\
\text { included in the model }\end{array}$ & $\begin{array}{l}\text { Bring forward treatment } \\
\text { (incorrect diagnoses not } \\
\text { modeled) }\end{array}$ & $\begin{array}{l}\text { Bring forward treatment } \\
\text { (incorrect diagnoses not } \\
\text { modeled) }\end{array}$ & $\begin{array}{l}\text { A disease progression } \\
\text { model is applied on true } \\
\text { and false positive and } \\
\text { negative diagnoses }\end{array}$ & $\begin{array}{l}\text { A disease progression } \\
\text { model is applied on true } \\
\text { and false positive and } \\
\text { negative diagnoses }\end{array}$ \\
\hline Diagnostic care setting & $\begin{array}{l}\text { Existing primary and } \\
\text { secondary care services in } \\
\text { England }\end{array}$ & $\begin{array}{l}\text { GP and specialist centers } \\
\text { in UK }\end{array}$ & $\begin{array}{l}\text { A specialized Alzheimer } \\
\text { disease center (tertiary } \\
\text { Alzheimer disease clinic) }\end{array}$ & $\begin{array}{l}\text { A specialized Alzheimer } \\
\text { disease center }\end{array}$ \\
\hline Study population & $\begin{array}{l}\text { Patients in an early state } \\
\text { of dementia }\end{array}$ & $\begin{array}{l}\text { Patients with } \\
\text { undiagnosed } A D\end{array}$ & $\begin{array}{l}\text { Patients with mild or } \\
\text { moderate dementia (at } \\
\text { presentation to an } \\
\text { Alzheimer disease center) }\end{array}$ & $\begin{array}{l}\text { patients with mild or } \\
\text { moderate dementia who } \\
\text { present to specialized AD } \\
\text { centers }\end{array}$ \\
\hline Primary patient level data & $\mathrm{N} / \mathrm{A}$ & N/A & $\mathrm{N} / \mathrm{A}$ & N/A \\
\hline Perspective & Societal & $\begin{array}{l}\text { Health care payer and } \\
\text { societal }\end{array}$ & Societal & Societal \\
\hline Time horizon & 10 years & 10 years & 18 months & 18 months \\
\hline Outcome measure & Net benefit & ICER & ICER & ICER \\
\hline Main results & $\begin{array}{l}\text { NPV over } 10 \text { years: }-£ 950 \\
\text { million. A gain of between } \\
0.01 \text { and } 0.02 \text { QALYs per } \\
\text { person year would render } \\
\text { the service cost-effective }\end{array}$ & $\begin{array}{l}\text { Early assessment and } \\
\text { treatment dominates } \\
\text { both other options under } \\
\text { evaluation }\end{array}$ & $\begin{array}{l}\text { ICER DSC MRI: } \\
\$ 479,500 / Q A L Y \text { compared } \\
\text { with the usual diagnostic } \\
\text { work-up. Visual or } \\
\text { quantitative SPECT was } \\
\text { dominated }\end{array}$ & $\begin{array}{l}\text { FDG PET and sPECT were } \\
\text { dominated. ICER DSC } \\
\text { MRI: } \$ 598,800 / Q A L Y \\
\text { compared to standard } \\
\text { examination. }\end{array}$ \\
\hline Conclusion & $\begin{array}{l}\text { This presents for debate } \\
\text { support for developing } \\
\text { nationwide services for } \\
\text { early identification and } \\
\text { treatment of dementia }\end{array}$ & $\begin{array}{l}\text { The analysis suggest } \\
\text { substantial benefits in } \\
\text { terms of both patient and } \\
\text { economic outcomes for } \\
\text { early assessment and } \\
\text { early treatment of AD }\end{array}$ & $\begin{array}{l}\text { Adding functional } \\
\text { neuroimaging to usual } \\
\text { diagnostic regimen is not } \\
\text { cost-effective given the } \\
\text { effectiveness of currently } \\
\text { available therapies }\end{array}$ & $\begin{array}{l}\text { PET may have high } \\
\text { diagnostic accuracy, but } \\
\text { adding it to the standard } \\
\text { diagnostic regimen at } A D \\
\text { clinics would yield limited, } \\
\text { if any, benefits at very } \\
\text { high costs }\end{array}$ \\
\hline
\end{tabular}

Abbreviations: AD, Alzheimer's disease; CT, computerized tomography; DSC, dynamic susceptibility-weighted contrastenhanced; FDG, fluorodeoxyglucose; ICER, incremental cost-effectiveness ratio; MRI, magnetic resonance imaging; N/A, not applicable; NICE, National Institute for Health and Clinical Excellence; NPV, net present value; NS, not stated; PET, positron emission tomography; QALE, quality adjusted life expectancy; QALY, quality adjusted life year; SPECT, single photon emission computed tomography; UK, United Kingdom; US, United States; AU, Australia; 


\begin{tabular}{|c|c|c|c|c|}
\hline Moulin-Romsee et al.[27] & Silverman et al.[28] & Simon et al.[29] & Weimer et al.[30] & Wolfs et al.[31] \\
\hline 2005 & 2002 & 1985 & 2009 & 2009 \\
\hline Belgium & US & US & US & $\mathrm{NL}$ \\
\hline $\begin{array}{l}\text { Estimate the economic } \\
\text { effects of incorporating } \\
\text { FDG PET in the diagnostic } \\
\text { work-up of AD }\end{array}$ & $\begin{array}{l}\text { Compare the relative } \\
\text { value of a conventional } \\
\text { and proposed approach } \\
\text { using PET to assess early } \\
\text { AD }\end{array}$ & $\begin{array}{l}\text { Estimating the health } \\
\text { benefits and economic } \\
\text { costs of using alternative } \\
\text { scanning strategies for } \\
\text { diagnosing dementia }\end{array}$ & $\begin{array}{l}\text { Evaluates the costs and } \\
\text { benefits of the early } \\
\text { identification and } \\
\text { treatment of AD patients }\end{array}$ & $\begin{array}{l}\text { Evaluate the cost- } \\
\text { effectiveness of } \\
\text { integrated } \\
\text { multidisciplinary } \\
\text { diagnostic facility for } \\
\text { dementia }\end{array}$ \\
\hline Modeling & Modeling & Modeling & Modeling & $\begin{array}{l}\text { Trial-based economic } \\
\text { evaluation }\end{array}$ \\
\hline $\begin{array}{l}\text { Decision-tree (based upon } \\
\text { model Silverman et al.) }\end{array}$ & Decision-tree & Decision-tree & Static & N/A \\
\hline Static & Static & Static & $\begin{array}{l}\text { state independent } \\
\text { mathematical model }\end{array}$ & $\mathrm{N} / \mathrm{A}$ \\
\hline $\begin{array}{l}\text { Synthesizing head-to- } \\
\text { head comparisons where } \\
\text { relevant trials do not exist }\end{array}$ & $\begin{array}{l}\text { Synthesizing head-to- } \\
\text { head comparisons where } \\
\text { relevant trials do not exist }\end{array}$ & $\begin{array}{l}\text { Synthesizing head-to- } \\
\text { head comparisons where } \\
\text { relevant trials do not exist }\end{array}$ & $\begin{array}{l}\text { Informing decisions in the } \\
\text { absence of hard data }\end{array}$ & $\mathrm{N} / \mathrm{A}$ \\
\hline $\begin{array}{l}\text { Routine practice for the } \\
\text { diagnosis of } A D\end{array}$ & $\begin{array}{l}\text { Current practice for } \\
\text { expert evaluation of } \\
\text { dementia }\end{array}$ & $\begin{array}{l}\text { CT scanning when } \\
\text { historical or physical } \\
\text { findings suggest a } \\
\text { treatable illness (S-CT) }\end{array}$ & $\begin{array}{l}\text { Later diagnosis and drug } \\
\text { treatment }\end{array}$ & $\begin{array}{l}\text { Diagnosis made by GP or } \\
\text { existing regional services }\end{array}$ \\
\hline $\begin{array}{l}\text { FDG PET incorporated in } \\
\text { routine practice }\end{array}$ & $\begin{array}{l}\text { FDG PET after ruling out } \\
\text { other conditions }\end{array}$ & $\begin{array}{l}\text { (1) Routine evaluation } \\
\text { with CT scanning (R-CT); } \\
\text { ( } 2 \text { ) Routine MRI to } \\
\text { replace routine CT (R- } \\
\text { MRI) }\end{array}$ & $\begin{array}{l}\text { Immediate diagnosis and } \\
\text { intervention }\end{array}$ & $\begin{array}{l}\text { Multidisciplinary } \\
\text { assessment combining } \\
\text { hospital setting and } \\
\text { community mental health } \\
\text { setting }\end{array}$ \\
\hline $\begin{array}{l}\text { A summary effect of } \\
\text { overtreatment and under } \\
\text { treatment is on false } \\
\text { diagnoses }\end{array}$ & $\begin{array}{l}\text { A summary effect of } \\
\text { overtreatment and under } \\
\text { treatment is on false } \\
\text { diagnoses }\end{array}$ & $\begin{array}{l}\text { (quality adjusted) life } \\
\text { expectancy of patients } \\
\text { with under-diagnosed } \\
\text { treatable conditions }\end{array}$ & $\begin{array}{l}\text { Bring forward treatment } \\
\text { (incorrect diagnoses not } \\
\text { modeled) }\end{array}$ & N/A \\
\hline NS & $\begin{array}{l}\text { Current practice } \\
\text { standards for expert } \\
\text { evaluation of dementia }\end{array}$ & NS & NS & $\begin{array}{l}\text { GP or home visit and } \\
\text { Geriatric Medicine and } \\
\text { Geriatric Psychiatry } \\
\text { hospital departments }\end{array}$ \\
\hline NS & $\begin{array}{l}\text { geriatric patients with } \\
\text { early symptoms of } \\
\text { cognitive decline }\end{array}$ & $\begin{array}{l}\text { individuals aged } 60,70 \text {, or } \\
80 \text { and presenting with a } \\
\text { dementing illness }\end{array}$ & $\begin{array}{l}\text { AD patients suffering } \\
\text { from cognitive decline }\end{array}$ & $\begin{array}{l}\text { patients suspected of } \\
\text { having dementia or a } \\
\text { cognitive disorder (age } \\
55+\text { ) }\end{array}$ \\
\hline N/A & N/A & N/A & N/A & $\begin{array}{l}\text { Quality of life and } \\
\text { resource consumption } \\
\text { data on } 219 \text { patients }\end{array}$ \\
\hline NS & Health care payer & NS & Societal & Societal \\
\hline NS & 12 months & Lifetime & Lifetime & 12 months \\
\hline $\begin{array}{l}\text { Cost savings per accurate } \\
\text { diagnosis }\end{array}$ & $\begin{array}{l}\text { Costs per accurate } \\
\text { diagnoses }\end{array}$ & ICER & Net benefit & ICER \\
\hline $\begin{array}{l}\text { Cost-savings per accurate } \\
\text { diagnosis ranged from } \\
623-6110 \text { Euro in favor of } \\
\text { the proposed algorithm } \\
\text { with PET }\end{array}$ & $\begin{array}{l}\text { Costs per correct } \\
\text { diagnosis by the } \\
\text { conventional algorithm: } \\
\$ 5,185 \text { and proposed } \\
\text { algorithm: } \$ 4,047\end{array}$ & $\begin{array}{l}\text { Cost per additional year } \\
\text { of QALE from S-CT to R-CT } \\
\text { is below } \$ 50,000 \text {. } \\
\text { Comparing R-MRI to R-CT } \\
\text { incremental cost ranges } \\
\text { from } \$ 46,000 \text { to } \$ 144,000\end{array}$ & $\begin{array}{l}\text { Early identification and } \\
\text { treatment potentially } \\
\text { result in large, positive } \\
\text { net social benefits as well } \\
\text { as positive net savings }\end{array}$ & $\begin{array}{l}\text { ICER: } € 1267 / Q A L Y \text {. This } \\
\text { estimate is within an } \\
\text { acceptable range of } \\
\text { uncertainty }\end{array}$ \\
\hline $\begin{array}{l}\text { Incorporating FDG PET in } \\
\text { the clinical work up can } \\
\text { result in substantial } \\
\text { benefit in terms of health- } \\
\text { care cost savings and } \\
\text { benefit for the patient. }\end{array}$ & $\begin{array}{l}\text { Improved care can be } \\
\text { economically achieved } \\
\text { through incorporation of } \\
\text { PET into the diagnostic } \\
\text { work-up }\end{array}$ & $\begin{array}{l}\text { Given current treatment } \\
\text { limitations in dementia it } \\
\text { appears that MRI will } \\
\text { have little immediate } \\
\text { health impact on this } \\
\text { problem }\end{array}$ & $\begin{array}{l}\text { Early diagnosis and } \\
\text { treatment of } A D \text { are } \\
\text { socially desirable in terms } \\
\text { of increasing economic } \\
\text { efficiency, and fiscally } \\
\text { attractive }\end{array}$ & $\begin{array}{l}\text { Integrated } \\
\text { multidisciplinary } \\
\text { diagnostic facility is cost- } \\
\text { effective for the diagnosis } \\
\text { and management of } \\
\text { dementia in community } \\
\text { patients }\end{array}$ \\
\hline
\end{tabular}

* Part of the model was described in Getsios et.al. [32]

+ Part of the model was described in Neuman et.al. [33]

‡ Model type was valued as "static" if not represented by a mathematical model (e.g., when the effect was summarized

in one or more fixed outcome values)

$\S$ Model types were based on Buxton et.al. [19]

ๆ Additional strategies evaluated in a sensitivity analysis are not stated 
Table 2 displays the application of the CHEC list [20] on the trial-based economic evaluation. A time horizon of 1 year was considered too short for the inclusion of all relevant costs and consequences and generalizability was insufficiently addressed.

\section{Table 2: Scores on the CHEC list of trial-based economic evaluation studies}

\begin{tabular}{lc}
\hline CHEC-list Item & Wolfs et \\
& al.[31] \\
\hline 1. Is the study population clearly described? & $\mathrm{Y}$ \\
2. Are competing alternatives clearly described? & $\mathrm{Y}$ \\
3. Is a well-defined research question posed in answerable form? & $\mathrm{Y}$ \\
4. Is the economic study design appropriate to the stated objective? & $\mathrm{Y}$ \\
5. Is the chosen time horizon appropriate in order to include relevant costs and consequences? & $\mathrm{N}$ \\
6. Is the actual perspective chosen appropriate? & $\mathrm{Y}$ \\
7. Are all important and relevant costs for each alternative identified? & $\mathrm{Y}$ \\
8. Are all costs measured appropriately in physical units? & $\mathrm{Y}$ \\
9. Are costs valued appropriately? & $\mathrm{Y}$ \\
10. Are all important and relevant outcomes for each alternative identified? & $\mathrm{Y}$ \\
11. Are all outcomes measured appropriately? & $\mathrm{Y}$ \\
12. Are outcomes valued appropriately? & $\mathrm{Y}$ \\
13. Is an incremental analysis of costs and outcomes of alternatives performed? & $\mathrm{Y}$ \\
14. Are all future costs and outcomes discounted appropriately? & $\mathrm{Y}$ \\
15. Are all important variables, whose values are uncertain, appropriately subjected to sensitivity & $\mathrm{Y}$ \\
analysis? & \\
16. Do the conclusions follow from the data reported? & $\mathrm{Y}$ \\
17. Does the study discuss the generalizability of the results to other settings and patient/client & $\mathrm{N}$ \\
groups? & \\
18. Does the article indicate that there is no potential conflict of interest of study researcher(s) and \\
funder(s)? & $\mathrm{Y}$ \\
19. Are ethical and distributional issues discussed appropriately? &
\end{tabular}

Abbreviations: $N$, the item was not fulfilled or insufficient information was available in the article to assess the item; $Y$, both reviewers agreed that the study paid sufficient attention to an item

Table 3 displays the results of the quality assessment using the framework for decision-analytic models [21]. Twenty framework items required scoring by the third reviewer (J.S.); two were due to dissimilarities between the two reviewers that could not be resolved by discussion. Items in several topics were not fulfilled or were insufficiently addressed by most included studies. The following four were also considered of importance regarding this review's focus on the diagnostic aspects of the decision models. Model scope was considered insufficiently addressed because a lifetime horizon was disregarded and the population and setting were mostly not addressed. The options under evaluation were considered not fulfilled because many studies did not evaluate all feasible options or did not justify their exclusion, especially regarding combinations of diagnostic tests. Further, several items of the data identification were not addressed sufficiently, especially regarding the identification of key parameters. Lastly, according to the checklist, all types of uncertainty analyses were considered not described or not performed by almost all included studies. 
Study number, author, source

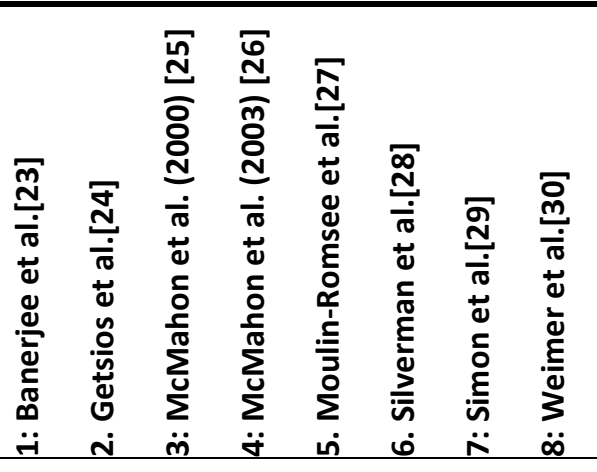

\begin{tabular}{|c|c|c|c|c|c|c|c|c|c|c|}
\hline & & & 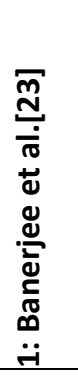 & 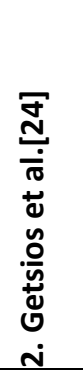 & 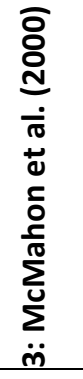 & 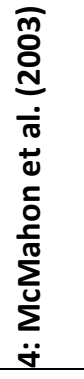 & 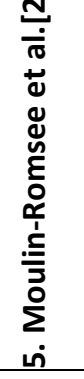 & 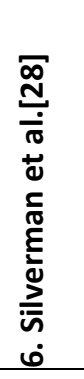 & 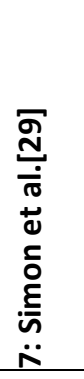 & 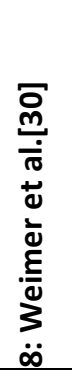 \\
\hline \multicolumn{11}{|l|}{ Structure (S) } \\
\hline \multirow{3}{*}{$\begin{array}{l}\text { S1: Statement of } \\
\text { decision } \\
\text { problem/objective }\end{array}$} & 1 & $\begin{array}{l}\text { Is there a clear statement of the decision } \\
\text { problem? }\end{array}$ & Y & $\mathrm{Y}$ & $\mathrm{N}$ & Y & Y & Y & Y & Y \\
\hline & 2 & $\begin{array}{l}\text { Is the objective of the evaluation and } \\
\text { model specified and consistent with the } \\
\text { stated decision problem? }\end{array}$ & Y & Y & $\mathrm{N} / \mathrm{A}$ & Y & Y & Y & Y & Y \\
\hline & 3 & Is the primary decision maker specified? & Y & $\mathrm{N}$ & $\mathrm{N}$ & $\mathrm{N}$ & $\mathrm{N}$ & Y & $\mathrm{N}$ & Y \\
\hline \multirow[t]{4}{*}{$\begin{array}{l}\text { S2: Statement of } \\
\text { scope/perspective }\end{array}$} & 1 & $\begin{array}{l}\text { Is the perspective of the model stated } \\
\text { clearly? }\end{array}$ & Y & $\mathrm{Y}$ & Y & Y & $\mathrm{N}$ & Y & $\mathrm{N}$ & $\mathrm{Y}$ \\
\hline & 2 & $\begin{array}{l}\text { Are the model inputs consistent with the } \\
\text { stated perspective? }\end{array}$ & $\mathrm{N}$ & $\mathrm{Y}$ & $\mathrm{Y}$ & Y & $\mathrm{N} / \mathrm{A}$ & Y & N/A & Y \\
\hline & $3 *$ & $\begin{array}{l}\text { Has the scope of the model been stated } \\
\text { and justified? }\end{array}$ & $\mathrm{N}$ & $\mathrm{N}$ & $\mathrm{N}$ & $\mathrm{N}$ & $\mathrm{N}$ & $\mathrm{N}$ & $\mathrm{N}$ & $\mathrm{N}$ \\
\hline & 4 & $\begin{array}{l}\text { Are the outcomes of the model consistent } \\
\text { with the perspective, scope and overall } \\
\text { objective of the model? }\end{array}$ & N/A & N/A & $\mathrm{N} / \mathrm{A}$ & N/A & $\mathrm{N} / \mathrm{A}$ & N/A & N/A & $\mathrm{N} / \mathrm{A}$ \\
\hline \multirow[t]{5}{*}{$\begin{array}{l}\text { S3: Rationale for } \\
\text { structure }\end{array}$} & 1 & $\begin{array}{l}\text { Has the evidence regarding the model } \\
\text { structure been described? }\end{array}$ & $\mathrm{N}$ & $Y$ & $Y$ & $Y$ & Y & $Y$ & $\mathrm{~N}$ & $Y$ \\
\hline & $2+$ & $\begin{array}{l}\text { Is the structure of the model consistent } \\
\text { with a coherent theory of the health } \\
\text { condition under evaluation? }\end{array}$ & $\mathrm{N}$ & $Y$ & Y & $Y$ & Y & $Y$ & $Y$ & $Y$ \\
\hline & $3 \ddagger$ & $\begin{array}{l}\text { Have any competing theories regarding } \\
\text { model structure been considered? }\end{array}$ & $\mathrm{N}$ & $\mathrm{N}$ & $\mathrm{N}$ & $\mathrm{N}$ & $\mathrm{N}$ & $\mathrm{N}$ & $\mathrm{N}$ & $\mathrm{N}$ \\
\hline & 4 & $\begin{array}{l}\text { Are the sources of data used to develop } \\
\text { the structure of the model specified? }\end{array}$ & $\mathrm{N}$ & $Y$ & Y & $Y$ & Y & $Y$ & $\mathrm{~N}$ & $Y$ \\
\hline & 5 & $\begin{array}{l}\text { Are the causal relationships described by } \\
\text { the model structure justified } \\
\text { appropriately? }\end{array}$ & $Y$ & $Y$ & $\mathrm{Y}$ & $Y$ & Y & $Y$ & Y & $Y$ \\
\hline \multirow[t]{2}{*}{$\begin{array}{l}\text { S4: Structural } \\
\text { assumptions }\end{array}$} & 1 & $\begin{array}{l}\text { Are the structural assumptions } \\
\text { transparent and justified? }\end{array}$ & $Y$ & $Y$ & $\mathrm{Y}$ & $Y$ & Y & $Y$ & $Y$ & $Y$ \\
\hline & 2 & $\begin{array}{l}\text { Are the structural assumptions reasonable } \\
\text { given the overall objective, perspective } \\
\text { and scope of the model? }\end{array}$ & N/A & N/A & N/A & N/A & $\mathrm{N} / \mathrm{A}$ & N/A & N/A & $\mathrm{N} / \mathrm{A}$ \\
\hline \multirow[t]{3}{*}{$\begin{array}{l}\text { S5: } \\
\text { Strategies/comparator } \\
\text { S }\end{array}$} & 1 & $\begin{array}{l}\text { Is there a clear definition of the options } \\
\text { under evaluation? }\end{array}$ & $\mathrm{N}$ & $Y$ & Y & $Y$ & Y & $Y$ & $Y$ & $\mathrm{~N}$ \\
\hline & 2 & $\begin{array}{l}\text { Have all feasible and practical options } \\
\text { been evaluated? }\end{array}$ & $\mathrm{N}$ & $\mathrm{N}$ & $Y$ & $Y$ & $\mathrm{~N}$ & $\mathrm{~N}$ & $\mathrm{~N}$ & $Y$ \\
\hline & 3 & $\begin{array}{l}\text { Is there justification for the exclusion of } \\
\text { feasible options? }\end{array}$ & $\mathrm{N}$ & $\mathrm{N}$ & $Y$ & Y & $\mathrm{N}$ & $\mathrm{N}$ & $\mathrm{N}$ & $\mathrm{N} / \mathrm{A}$ \\
\hline S6: Model type & 1 & $\begin{array}{l}\text { Is the chosen model type appropriate } \\
\text { given the decision problem and specified } \\
\text { causal relationships within the model? }\end{array}$ & $\mathrm{N}$ & Y & Y & $Y$ & Y & $Y$ & Y & $\mathrm{N}$ \\
\hline
\end{tabular}




\begin{tabular}{|c|c|c|c|c|c|c|c|c|c|c|}
\hline & & & 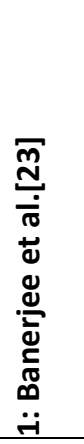 & 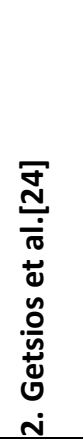 & 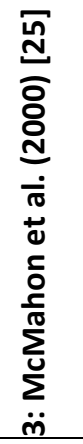 & 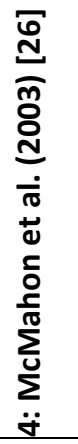 & 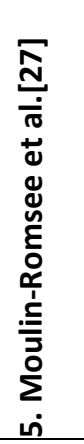 & 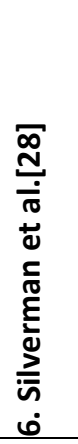 & 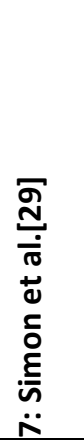 & 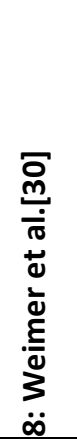 \\
\hline \multirow[t]{4}{*}{ S7: Time horizon } & 1 & $\begin{array}{l}\text { Is the time horizon of the model sufficient } \\
\text { to reflect all important differences } \\
\text { between options? }\end{array}$ & $\mathrm{Y}$ & $\mathrm{Y}$ & $\mathrm{Y}$ & Y & $\mathrm{N}$ & $\mathrm{Y}$ & $\mathrm{Y}$ & $\mathrm{Y}$ \\
\hline & 2 & $\begin{array}{l}\text { Is the time horizon of the model, and the } \\
\text { duration of treatment and treatment } \\
\text { effect described and justified? }\end{array}$ & $\mathrm{N}$ & Y & Y & Y & N/A & Y & Y & $\mathrm{N}$ \\
\hline & 3 & Has a lifetime horizon been used? & $\mathrm{N}$ & $\mathrm{N}$ & $\mathrm{N}$ & $\mathrm{N}$ & $\mathrm{N}$ & $\mathrm{N}$ & Y & $\mathrm{Y}$ \\
\hline & 4 & $\begin{array}{l}\text { If not, has a shorter time horizon been } \\
\text { justified? }\end{array}$ & $\mathrm{N}$ & $\mathrm{N}$ & $\mathrm{Y}$ & Y & $\mathrm{N}$ & $\mathrm{N}$ & N/A & $N / A$ \\
\hline $\begin{array}{l}\text { S8: Disease } \\
\text { states/pathways }\end{array}$ & $1 \S$ & $\begin{array}{l}\text { Do the disease states (state transition } \\
\text { model) or the pathways (decision tree } \\
\text { model) reflect the underlying biological } \\
\text { process of the disease in question and the } \\
\text { impact of interventions? }\end{array}$ & $\mathrm{N}$ & Y & Y & Y & Y & Y & Y & $\mathrm{N}$ \\
\hline S9: Cycle length & 1 & $\begin{array}{l}\text { Is the cycle length defined and justified in } \\
\text { terms of the natural history of disease? }\end{array}$ & N/A & N/A & $\mathrm{Y}^{* *}$ & $\mathrm{Y}^{* *}$ & N/A & N/A & N/A & Y \\
\hline \multicolumn{11}{|l|}{ Data (D) } \\
\hline \multirow[t]{6}{*}{ D1: Data identification } & 1 & $\begin{array}{l}\text { Are the data identification methods } \\
\text { transparent and appropriate given the } \\
\text { objectives of the model? }\end{array}$ & $\mathrm{N}$ & $Y^{* *}$ & $\mathrm{~N}$ & $\mathrm{~N}$ & Y & Y & $\mathrm{N}$ & $\mathrm{N}$ \\
\hline & 2 & $\begin{array}{l}\text { Where choices have been made between } \\
\text { data sources, are these justified } \\
\text { appropriately? }\end{array}$ & $\mathrm{N}$ & $\mathrm{Y}^{* *}$ & $\mathrm{~N}$ & Y & Y & Y & $\mathrm{N}$ & $\mathrm{N}$ \\
\hline & 3 & $\begin{array}{l}\text { Has particular attention been paid to } \\
\text { identifying data for the important } \\
\text { parameters in the model? }\end{array}$ & $\mathrm{N}$ & Y & $\mathrm{Y}$ & Y & Y & Y & Y & Y \\
\hline & 4 & $\begin{array}{l}\text { Has the process of selecting key } \\
\text { parameters been justified and systematic } \\
\text { methods used to identify the most } \\
\text { appropriate data? }\end{array}$ & N/A & $\mathrm{N}$ & $\mathrm{N}$ & $N$ & $\mathrm{~N}$ & $\mathrm{~N}$ & $\mathrm{~N}$ & $\mathrm{~N}$ \\
\hline & 5 & $\begin{array}{l}\text { Has the quality of the data been assessed } \\
\text { appropriately? }\end{array}$ & $\mathrm{N}$ & $\mathrm{Y}^{* *}$ & $\mathrm{~N}$ & $\mathrm{~N}$ & $\mathrm{Y}$ & Y & $\mathrm{N}$ & $\mathrm{N}$ \\
\hline & 6 & $\begin{array}{l}\text { Where expert opinion has been used, are } \\
\text { the methods described and justified? }\end{array}$ & N/A & N/A & Y & Y & N/A & N/A & $\mathrm{N}$ & $\mathrm{N} / \mathrm{A}$ \\
\hline $\begin{array}{l}\text { D2: Pre-model data } \\
\text { analysis }\end{array}$ & 1 & $\begin{array}{l}\text { Are the pre-model data analysis } \\
\text { methodology based on justifiable } \\
\text { statistical and epidemiological } \\
\text { techniques? }\end{array}$ & N/A & $\mathrm{Y}^{* *}$ & $\mathrm{Y}^{* *}$ & $\mathrm{Y}^{* *}$ & N/A & N/A & N/A & Y \\
\hline \multirow[t]{4}{*}{ D2a: baseline data } & 1 & $\begin{array}{l}\text { Is the choice of baseline data described } \\
\text { and justified? }\end{array}$ & $\mathrm{N}$ & $\mathrm{Y}^{* *}$ & Y & $Y$ & $\mathrm{Y}$ & Y & Y & $\mathrm{Y}$ \\
\hline & 2 & $\begin{array}{l}\text { Are transition probabilities calculated } \\
\text { appropriately? }\end{array}$ & N/A & N/A & $\mathrm{Y}^{* *}$ & $\mathrm{Y}^{* *}$ & Y & Y & Y & Y \\
\hline & 3 & $\begin{array}{l}\text { Has a half cycle correction been applied to } \\
\text { both cost and outcome? }\end{array}$ & N/A & N/A & $\mathrm{N}^{* *}$ & $\mathrm{~N}^{* *}$ & N/A & N/A & N/A & $\mathrm{N} / \mathrm{A}$ \\
\hline & 4 & If not, has this omission been justified? & N/A & $\mathrm{N} / \mathrm{A}$ & $\mathrm{N}^{* *}$ & $\mathrm{~N} * *$ & N/A & N/A & N/A & $\mathrm{N} / \mathrm{A}$ \\
\hline
\end{tabular}




\begin{tabular}{|c|c|c|c|c|c|c|c|c|c|c|}
\hline & & & 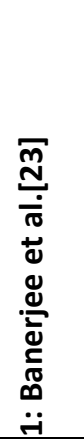 & 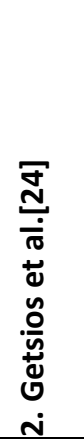 & 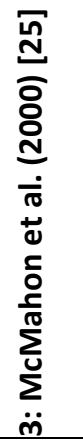 & 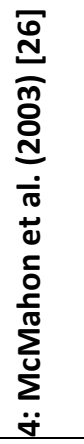 & 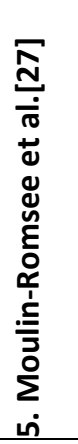 & 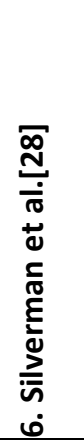 & 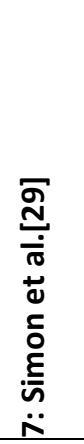 & 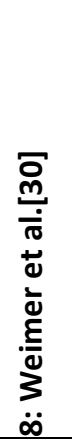 \\
\hline \multirow[t]{5}{*}{$\begin{array}{l}\text { D2b: treatment effects } \\
\text { and diagnostic } \\
\text { accuracy }\end{array}$} & 19 & $\begin{array}{l}\text { If relative diagnostic accuracy have been } \\
\text { derived from trial data, have they been } \\
\text { synthesised using appropriate techniques? }\end{array}$ & N/A & N/A & $\mathrm{Y}$ & $\mathrm{Y}$ & $Y$ & $\mathrm{Y}$ & $\mathrm{Y}$ & $\mathrm{N} / \mathrm{A}$ \\
\hline & $2 \#$ & $\begin{array}{l}\text { Have the methods and assumptions used } \\
\text { to extrapolate diagnostic accuracy to final } \\
\text { outcomes been documented and } \\
\text { justified? }\end{array}$ & N/A & N/A & Y & Y & $Y$ & Y & Y & $N / A$ \\
\hline & 3 & $\begin{array}{l}\text { Have alternative assumptions been } \\
\text { explored through sensitivity analysis? }\end{array}$ & N/A & Y & Y & Y & $Y$ & Y & $\mathrm{N}$ & $\mathrm{N} / \mathrm{A}$ \\
\hline & 4 & $\begin{array}{l}\text { Have assumptions regarding the } \\
\text { continuing effect of treatment once } \\
\text { treatment is complete been documented } \\
\text { and justified? }\end{array}$ & N/A & Y & N/A & N/A & N/A & N/A & $\mathrm{N} / \mathrm{A}$ & $\mathrm{N} / \mathrm{A}$ \\
\hline & 5 & $\begin{array}{l}\text { Have alternative assumptions been } \\
\text { explored through sensitivity analysis? }\end{array}$ & N/A & Y & N/A & N/A & N/A & N/A & N/A & $\mathrm{N} / \mathrm{A}$ \\
\hline \multirow[t]{3}{*}{$\begin{array}{l}\text { D2c: quality-of-life } \\
\text { weights (utilities) }\end{array}$} & 1 & $\begin{array}{l}\text { Are the utilities incorporated into the } \\
\text { model appropriate? }\end{array}$ & N/A & Y & Y & Y & N/A & N/A & Y & Y \\
\hline & 2 & $\begin{array}{l}\text { Is the source for the utility weights } \\
\text { referenced? }\end{array}$ & N/A & Y & Y & Y & N/A & N/A & $\mathrm{N}$ & Y \\
\hline & 3 & $\begin{array}{l}\text { Are the methods of derivation for the } \\
\text { utility weights justified? }\end{array}$ & N/A & Y & Y & Y & N/A & N/A & $\mathrm{N}$ & $\mathrm{N} / \mathrm{A}$ \\
\hline \multirow[t]{5}{*}{ D3: Data incorporation } & 1 & $\begin{array}{l}\text { Have all data incorporated into the model } \\
\text { been described and referenced in } \\
\text { sufficient detail? }\end{array}$ & Y & Y & Y & Y & $\mathrm{N}$ & Y & Y & Y \\
\hline & 2 & $\begin{array}{l}\text { Has the use of mutually inconsistent data } \\
\text { been justified (i.e. are assumptions and } \\
\text { choices appropriate)? }\end{array}$ & N/A & N/A & N/A & N/A & N/A & N/A & N/A & N/A \\
\hline & 3 & $\begin{array}{l}\text { Is the process of data incorporation } \\
\text { transparent? }\end{array}$ & Y & Y & Y & Y & Y & Y & Y & Y \\
\hline & 4 & $\begin{array}{l}\text { If data have been incorporated as } \\
\text { distributions, has the choice of } \\
\text { distribution for each parameter been } \\
\text { described and justified? }\end{array}$ & N/A & $\mathrm{Y}^{* *}$ & N/A & N/A & N/A & N/A & N/A & Y \\
\hline & 5 & $\begin{array}{l}\text { If data have been incorporated as } \\
\text { distributions, is it clear that second order } \\
\text { uncertainty is reflected? }\end{array}$ & N/A & $\mathrm{Y}$ & N/A & N/A & N/A & N/A & N/A & $\mathrm{N}$ \\
\hline \multirow[t]{2}{*}{$\begin{array}{l}\text { D4: Assessment of } \\
\text { uncertainty }\end{array}$} & 1 & $\begin{array}{l}\text { Have the four principal types of } \\
\text { uncertainty been addressed? }\end{array}$ & $\mathrm{N}$ & $\mathrm{N}$ & $\mathrm{N}$ & $\mathrm{N}$ & $\mathrm{N}$ & $\mathrm{N}$ & $\mathrm{N}$ & $\mathrm{N}$ \\
\hline & 2 & $\begin{array}{l}\text { If not, has the omission of particular forms } \\
\text { of uncertainty been justified? }\end{array}$ & $\mathrm{N}$ & $\mathrm{N}$ & $\mathrm{N}$ & $\mathrm{N}$ & $\mathrm{N}$ & $\mathrm{N}$ & $\mathrm{N}$ & $\mathrm{N}$ \\
\hline D4a: methodological & 1 & $\begin{array}{l}\text { have methodological uncertainties been } \\
\text { addressed by running alternative versions } \\
\text { of the model with different } \\
\text { methodological assumptions? }\end{array}$ & $\mathrm{N}$ & $\mathrm{N}$ & $\mathrm{N}$ & $\mathrm{N}$ & $\mathrm{N}$ & $\mathrm{N}$ & $\mathrm{N}$ & $\mathrm{N}$ \\
\hline
\end{tabular}




\begin{tabular}{|c|c|c|c|c|c|c|c|c|c|c|}
\hline & & & 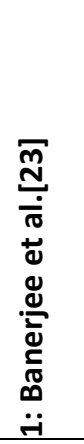 & 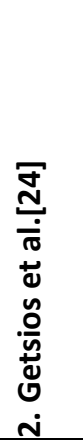 & 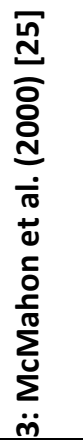 & 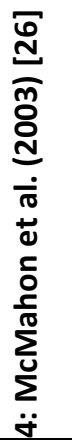 & 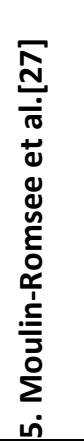 & 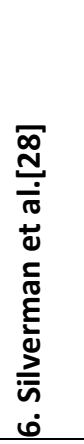 & 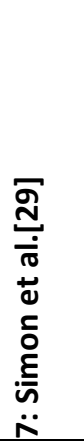 & 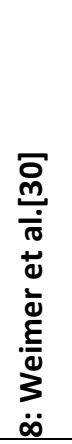 \\
\hline D4b: structural & 1 & $\begin{array}{l}\text { is there evidence that structural } \\
\text { uncertainties have been addressed via } \\
\text { sensitivity analysis? }\end{array}$ & $\mathrm{N}$ & $\mathrm{N}$ & $\mathrm{N}$ & $\mathrm{Y}$ & $\mathrm{N}$ & $\mathrm{Y}$ & $\mathrm{N}$ & $Y$ \\
\hline D4c: heterogeneity & 1 & $\begin{array}{l}\text { has heterogeneity been dealt with by } \\
\text { running the model separately for different } \\
\text { subgroups? }\end{array}$ & $\mathrm{N}$ & $\mathrm{N}$ & $\mathrm{N}$ & $\mathrm{N}$ & $\mathrm{N}$ & $\mathrm{N}$ & Y & Y \\
\hline \multirow[t]{3}{*}{ D4d: parameter } & 1 & $\begin{array}{l}\text { are the methods of assessment of } \\
\text { parameter uncertainty appropriate? }\end{array}$ & $\mathrm{N}$ & Y & $\mathrm{N}$ & $\mathrm{N}$ & $\mathrm{N}$ & $\mathrm{N}$ & $\mathrm{N}$ & Y \\
\hline & 2 & $\begin{array}{l}\text { has probabilistic sensitivity analysis been } \\
\text { done, if not, has this been justified? }\end{array}$ & $\mathrm{N}$ & Y & $\mathrm{N}$ & $\mathrm{N}$ & $\mathrm{N}$ & $\mathrm{N}$ & $\mathrm{N}$ & $\mathrm{N}$ \\
\hline & 3 & $\begin{array}{l}\text { If data are incorporated as point } \\
\text { estimates, are the ranges used for } \\
\text { sensitivity analysis stated clearly and } \\
\text { justified? }\end{array}$ & $\mathrm{N}$ & N/A & Y & $Y$ & Y & Y & Y & $\mathrm{N} / \mathrm{A}$ \\
\hline \multicolumn{11}{|l|}{ Consistency (C) } \\
\hline $\begin{array}{l}\text { C1: Internal } \\
\text { consistency }\end{array}$ & 1 & $\begin{array}{l}\text { Is there evidence that the mathematical } \\
\text { logic of the model has been tested } \\
\text { thoroughly before use? }\end{array}$ & $\mathrm{N}$ & $\mathrm{N}$ & $\mathrm{N}$ & $\mathrm{N}$ & $\mathrm{N}$ & $\mathrm{N}$ & $\mathrm{N}$ & $\mathrm{N}$ \\
\hline \multirow[t]{4}{*}{$\begin{array}{l}\text { C2: External } \\
\text { consistency }\end{array}$} & 1 & $\begin{array}{l}\text { Are the conclusions valid given the data } \\
\text { presented? }\end{array}$ & Y & Y & Y & Y & Y & Y & $Y$ & Y \\
\hline & 2 & $\begin{array}{l}\text { Are any counterintuitive results from the } \\
\text { model explained and justified? }\end{array}$ & N/A & N/A & N/A & N/A & N/A & N/A & N/A & $N / A$ \\
\hline & 3 & $\begin{array}{l}\text { If the model has been calibrated against } \\
\text { independent data, have any differences } \\
\text { been explained and justified? }\end{array}$ & N/A & N/A & N/A & N/A & N/A & N/A & N/A & $\mathrm{N} / \mathrm{A}$ \\
\hline & 4 & $\begin{array}{l}\text { Have the results of the model been } \\
\text { compared with those of previous models } \\
\text { and any differences in results explained? }\end{array}$ & $\mathrm{N}$ & $Y$ & $\mathrm{~N}$ & $Y$ & $\mathrm{~N}$ & $Y$ & $N$ & $\mathrm{~N}$ \\
\hline
\end{tabular}

Abbreviations: $\mathrm{N}$, item was not fulfilled or insufficient information was available; N/A, not applicable to the study or referred to a previous question scored with " $\mathrm{N}$ "; $\mathrm{Y}$, both reviewers agreed sufficient attention was paid to an item.

* According to the framework, the model scope should include the perspective, involved technologies, population, setting, and time horizon at the outset of the study.

† This item required expert knowledge in the field of AD. The structure of a model was therefore considered consistent with a coherent theory of $A D$ if it included the following basic elements in the diagnostic process: history taking, examination of cognition, and structural imaging $[43,44]$. Additionally, if treatment was included, it had to reflect cognition and a progressive decline according to a clinical measurement scale [14, 45] (e.g., the Mini-Mental State Examination (MMSE) or Clinical Dementia Rating).

¥ This item required expert knowledge in the field of AD. As stated in the introduction, new research criteria assigning to biomarkers a fundamental role in the diagnostic process have recently been developed. Applying these research criteria to the diagnostic process is considered a competing theory regarding model structure.

$\S$ This item required expert knowledge in the field of AD. The underlying biological process was considered appropriate if disease states or pathways reflected cognition.

I This item was changed to derivation of diagnostic accuracy.

\# This item was changed to extrapolation of diagnostic accuracy, according to its relevance within the hierarchical model of diagnostic efficacy [46].

** Information to score the item was only retrieved from the additional publication that described part of the model 


\section{DISCUSSION}

The objective of the present study was to systematically review the literature on economic evaluations of interventions for the early diagnosis of $A D$ and related disorders and to describe their methodological characteristics. Eight decision-analytic modeling studies and one trial-based economic evaluation were retrieved. Study quality was assessed using the framework for decisionanalytic models [21] and the CHEC list [20], and overall the results reflect considerable methodological quality. However, population and diagnostic setting (scope), interventions under evaluation, selection and quality assessment of key diagnostic input parameters, and uncertainty analyses were not fulfilled or were insufficiently addressed by most included studies. Although the study conclusions were considered valid given the data presented, the diversity in study characteristics and methodology could have a major impact on the cost-effectiveness estimate and do not allow for a valid comparison of the cost-effectiveness outcomes.

We discuss the applicability of the diagnostic part of existing decision models for the economic evaluation of the recently revised diagnostic research criteria for AD. Two aspects were considered of major importance as indicated by the framework for diagnostic test evaluation by Van den Bruel et al [11].

The first aspect regards diagnostic test accuracy, which is highly dependent on patient population characteristics, clinical setting and (patient selection by) results of previously performed tests [10]. Most studies left the above aspects insufficiently described (i.e.: the scope was minimally addressed). Because the newly developed research criteria are targeted on various disease severity in specialized centers, it is important to specify the corresponding targeted population and setting in decision analyses to enable their evaluation. Furthermore, most studies limited the diagnostic options under evaluation and minimally addressed sensitivity analyses to evaluate alternative diagnostic scenarios. Therefore, possible diagnostic strategies such as using biomarkers as add-on or triage were insufficiently evaluated. Furthermore, the newly developed research criteria divide the AD biomarkers into two categories (biomarkers of $\beta$-Amyloid deposition and of neuronal injury) and emphasized the importance of evaluating different combinations. This was insufficiently explored by the options under evaluation or by the sensitivity analyses. Questions on optimal decision-making when biomarker results contradict or when to stop testing were not answered.

The second aspect refers to the impact on patient outcome. Most studies in this review included only the impact of pharmacological treatment, which, in our opinion, underexposes the possible nonmedical effects in symptomatic predementia patients. Because current treatment guidelines do not advise medication in this disease phase and nonpharmacological treatments are mainly aimed at dementia-related symptoms [34], it leaves the diagnostic test impact mainly to nonmedical aspects [35], such as anxiety, depression, psychological well-being, (financial) decision-making, and future care planning [4], [36] and [37]).

\section{Recommendations}

Following these findings, three recommendations for future decision models to enable the evaluation of the new diagnostic research criteria can be made. First, we advise to describe in detail the model scope, including the intended goal as timely diagnosis or symptomatic predementia diagnosis, the population and clinical setting characteristics regarding disease state at the moment of diagnosis, and what diagnostic tests already have been performed in the population. We advise 
to describe these items separately as targeted by the decision model and as applied in the retrieved (literature) evidence on key diagnostic parameters such as test sensitivity and specificity.

Second, we advise to include a variety of possible test combinations as options under evaluation or to address these by structural sensitivity analyses (e.g., the study of McMahon et al [26]). At last, we recommend representing the diagnostic strategy by a decision tree, including probabilities for each test outcome and their corresponding non-medical consequences, followed by a Markov model or discrete event simulation describing long-term disease progression [38] (for example as applied by two of the included studies [25] and [26]).

\section{Limitations}

Both the CHEC-list for trial-based economic evaluations and the framework for quality assessment of decision-analytic models support the assessment of studies for a review. Judgments, however, remain subjective and therefore the use of three reviewers was adopted for this evaluation. We recommend that such a procedure be used for future studies. Also, several items in the framework for decision-analytic models were interpreted in different ways and therefore required resolution by a third reviewer (JS).

Furthermore, items including harm of testing, willingness to undergo a test, consequences of (false) diagnosis, purpose of testing regarding screening, diagnosis and prognosis, and place in the clinical pathway regarding other tests that have been performed are important in diagnostic test evaluation. However, major flaws on these items were not differentiated to minor flaws by using the quality assessment checklists. We applied a qualitative summary to enable such distinction though ideally a quantitative score would be applied that combines the different constructs of a model and assessed their relative importance to rate the quality of the studies.

Non-medical consequences of testing in the absence of direct clinical benefits are considered important. Quality of life scales are potentially useful though rarely capture all possible test effects and therefore specific instruments are advised to capture the nonmedical effects [35]. Retrieving quality of life estimates will be a challenge for future research. Meanwhile, willingness to pay estimates can, despite of challenges in obtaining reliable estimates, help to isolate the non-medical value [39]. Neumann et al [40] found that on average people are willing to pay about $\$ 450$ for an $A D$ test in absence of treatment and that a positive test result influences future planning in part of the subjects. If non-medical consequences could not be quantified they should be assessed qualitatively.

By excluding screening or risk assessment instruments we have not elaborated on the applicability of current decision models for the evaluation of the recently revised criteria for the presymptomatic pre-dementia phase. These criteria are however indicated as "strictly for research purposes only" and at this moment less relevant to evaluate for applicability in clinical practice.

Overall, the reviewers found that insufficient information was available for the assessment of all items of the framework for decision-analytic models, thereby increasing uncertainty about the interpretation and generalizability of the results. However, the quantity of publishable information is restricted by journal word count limits. The space available to describe all relevant aspects in detail is limited, especially for economic evaluations of diagnostic interventions, which most likely include both a diagnostic intervention and treatment options. A practical solution currently is to 
include an extensive appendix, as demonstrated by the model of Getsios et al [32] and, in a different field, by Van Gestel et al [41].

Issues of implementation were not included in the assessment instruments, though they may be of importance in assessing economic evaluations of diagnostic interventions for AD [16]. MRI and PET scans (and the production of PET tracers), for example, are not available in all hospitals. As a result, additional logistic effort or the reorganization of services may be necessary.

All included studies have been performed before the publication of the revised criteria and obviously therefore have not necessarily adopted the preferred model scope or methodology to compare a variety of test combinations. An example of an ongoing study adopting such scope and taking account the recommendations from this review is the LeARN study [42] (clinicaltrials.gov/ct2/show/NCT01450891) from which the results will be available in 2013.

\section{Conclusion}

A systematic review of economic evaluations of interventions for the early diagnosis of $A D$ and related disorders was conducted with the aim of describing their general and methodological characteristics. The search retrieved eight decision-analytic modeling studies and one trial-based economic evaluation. The overall results reflect considerable methodological quality. However, diversity among the study objective and characteristics was considerable and the topics scope, options under evaluation, data identification and uncertainty analyses were not fulfilled or insufficiently addressed. To apply current decision models for the assessment of the recently revised diagnostic research criteria for $A D$ we recommend to describe in detail the model scope, to include a variety of possible test combinations as options under evaluation, and to apply an explicit quality of life estimate to reflect the impact of non-medical aspects.

\section{ACKNOWLEDGMENTS}

This research was performed within the framework the Center for Translational Molecular Medicine (www.ctmm.nl), project LeARN (grant 02N-101).

\section{REFERENCES}

[1] M. Prince, R. Bryce, E. Albanese, A. Wimo, W. Ribeiro, C.P. Ferri The global prevalence of dementia: A systematic review and metaanalysis Alzheimers Dement, 9 (2013), pp. 63-75.e2

[2] Mathers C, Boerma T, Ma Fat D. The global burden of disease: 2004 update. World Health Organization. Available at: http://www.who.int/healthinfo/global_burden_disease/2004_report_update/en/index.html. Retrieved at July 2011.

[3] A. Wimo, L. Jonsson, J. Bond, M. Prince, B. Winblad The worldwide economic impact of dementia 2010 Alzheimers Dement, 9 (2013), pp. 1-11.e13

[4] Prince M, Bryce R, Ferri C. World Alzheimer Report 2011. Alzheimer's Disease International. Available at: http://www.alz.co.uk/research/worldreport/. Retrieved at May 2012.

[5] G. McKhann, D. Drachman, M. Folstein, R. Katzman, D. Price, E.M. Stadlan Clinical diagnosis of Alzheimer's disease: report of the NINCDS-ADRDA Work Group under the auspices of Department of Health and Human Services Task Force on Alzheimer's Disease Neurology, 34 (1984), pp. 939944 
[6] G.M. McKhann, D.S. Knopman, H. Chertkow, B.T. Hyman, C.R. Jack Jr., C.H. Kawas et al. The diagnosis of dementia due to Alzheimer's disease: recommendations from the National Institute on Aging-Alzheimer's Association workgroups on diagnostic guidelines for Alzheimer's disease Alzheimers Dement, 7 (2011), pp. 263-269

[7] M.S. Albert, S.T. DeKosky, D. Dickson, B. Dubois, H.H. Feldman, N.C. Fox et al. The diagnosis of mild cognitive impairment due to Alzheimer's disease: recommendations from the National Institute on Aging-Alzheimer's Association workgroups on diagnostic guidelines for Alzheimer's disease Alzheimers Dement, 7 (2011), pp. 270-279

[8] R.A. Sperling, P.S. Aisen, L.A. Beckett, D.A. Bennett, S. Craft, A.M. Fagan et al. Toward defining the preclinical stages of Alzheimer's disease: recommendations from the National Institute on AgingAlzheimer's Association workgroups on diagnostic guidelines for Alzheimer's disease Alzheimers Dement, 7 (2011), pp. 280-292

[9] C.R. Jack Jr., M.S. Albert, D.S. Knopman, G.M. McKhann, R.A. Sperling, M.C. Carrillo et al. Introduction to the recommendations from the National Institute on Aging-Alzheimer's Association workgroups on diagnostic guidelines for Alzheimer's disease Alzheimers Dement, 7 (2011), pp. 257-262

[10] J.A. Knottnerus, F. Buntinx The evidence base of clinical diagnosis: theory and methods of diagnostic research (2nd ed.)Wiley-Blackwell, Hoboken, NJ (2009)

[11] A. Van den Bruel, I. Cleemput, B. Aertgeerts, D. Ramaekers, F. Buntinx The evaluation of diagnostic tests: evidence on technical and diagnostic accuracy, impact on patient outcome and costeffectiveness is needed J Clin Epidemiol, 60 (2007), pp. 1116-1122

[12] A.H. Briggs, K. Claxton, M.J. Sculpher Decision modelling for health economic evaluation Oxford University Press, Oxford, United Kingdom (2006)

[13] M.C. Weinstein Recent developments in decision-analytic modelling for economic evaluation Pharmacoeconomics, 24 (2006), pp. 1043-1053

[14] Cohen JT, Neumann PJ. Decision analytic models for Alzheimer's disease: state of the art and future directions. 2008;4:212-22.

[15] Mauskopf JA, Paul JE, Grant DM, Stergachis A. The role of cost-consequence analysis in healthcare decision-making. 1998;13:277-88.

[16] MF Drummond, MJ Sculpher, GW Torrance, BJ O'Brien, GL Stoddart Methods for the economic evaluation of health care programmes (3rd ed.)Oxford University Press, New York (2005)

[17] V. Alton, I. Eckerlund, A. Norlund Health economic evaluations: how to find them Int J Technol Assess Health Care, 22 (2006), pp. 512-517

[18] F. Sassi, L. Archard, D. McDaid Searching literature databases for health care economic evaluations: how systematic can we afford to be? Med Care, 40 (2002), pp. 387-394

[19] M.J. Buxton, M.F. Drummond, B.A. Van Hout, R.L. Prince, T.A. Sheldon, T. Szucs et al. Modelling in economic evaluation: an unavoidable fact of life Health Econ, 6 (1997), pp. 217-227

[20] S. Evers, M. Goossens, H. de Vet, M. van Tulder, A. Ament Criteria list for assessment of methodological quality of economic evaluations: Consensus on Health Economic Criteria Int J Technol Assess Health Care, 21 (2005), pp. 240-245

[21] Z. Philips, L. Bojke, M. Sculpher, K. Claxton, S. Golder Good practice guidelines for decisionanalytic modelling in health technology assessment: a review and consolidation of quality assessment Pharmacoeconomics, 24 (2006), pp. 355-371

[22] Z. Philips, L. Ginnelly, M. Sculpher, K. Claxton, S. Golder, R. Riemsma et al. Review of guidelines for good practice in decision-analytic modelling in health technology assessment Health Technol Assess, 8 (2004) iii-iv, ix-xi, 1-158

[23] S. Banerjee, R. Wittenberg Clinical and cost effectiveness of services for early diagnosis and intervention in dementia Int J Geriatr Psychiatry, 24 (2009), pp. 748-754

[24] D Getsios, S Blume, KJ Ishak, G Maclaine, L Hernandez An economic evaluation of early assessment for Alzheimer's disease in the United Kingdom Alzheimers Dement,8(2012)pp.22-30

[25] P.M. McMahon, S.S. Araki, P.J. Neumann, G.J. Harris, G.S. Gazelle Cost-effectiveness of functional imaging tests in the diagnosis of Alzheimer disease Radiology, 217 (2000), pp. 58-68 
[26] P.M. McMahon, S.S. Araki, E.A. Sandberg, P.J. Neumann, G.S. Gazelle Cost-effectiveness of PET in the diagnosis of Alzheimer disease Radiology, 228 (2003), pp. 515-522

[27] G. Moulin-Romsee, A. Maes, D. Silverman, L. Mortelmans, K. Van Laere Cost-effectiveness of 18Ffluorodeoxyglucose positron emission tomography in the assessment of early dementia from a Belgian and European perspective Eur J Neurol, 12 (2005), pp. 254-263

[28] D.H. Silverman, J.L. Cummings, G.W. Small, S.S. Gambhir, W. Chen, J. Czernin et al. Added clinical benefit of incorporating 2-deoxy-2-[18F]fluoro-D-glucose with positron emission tomography into the clinical evaluation of patients with cognitive impairment Mol Imaging Biol, 4 (2002), pp. 283-293

[29] D.G. Simon, M.F. Lubin Cost-effectiveness of computerized tomography and magnetic resonance imaging in dementia Med Decis Making, 5 (1985), pp. 335-354

[30] D.L. Weimer, M.A. Sager Early identification and treatment of Alzheimer's disease: social and fiscal outcomes Alzheimers Dement, 5 (2009), pp. 215-226

[31] C.A. Wolfs, C.D. Dirksen, A. Kessels, J.L. Severens, F.R. Verhey Economic evaluation of an integrated diagnostic approach for psychogeriatric patients: results of a randomized controlled trial Arch Gen Psychiatry, 66 (2009), pp. 313-323

[32] D. Getsios, S. Blume, K.J. Ishak, G.D. Maclaine Cost effectiveness of Donepezil in the treatment of mild to moderate Alzheimer's disease: a UK evaluation using discrete-event simulation Pharmacoeconomics, 28 (2010), pp. 411-427

[33] P.J. Neumann, R.C. Hermann, K.M. Kuntz, S.S. Araki, S.B. Duff, J. Leon et al. Cost-effectiveness of Donepezil in the treatment of mild or moderate Alzheimer's disease Neurology, 52 (1999), pp. 1138-1145

[34] J. Olazaran, B. Reisberg, L. Clare, I. Cruz, J. Pena-Casanova, T. Del Ser et al. Nonpharmacological therapies in Alzheimer's disease: a systematic review of efficacy Dement Geriatr Cogn Disord, 30 (2010), pp. 161-178

[35] P.M. Bossuyt, K. McCaffery Additional patient outcomes and pathways in evaluations of testing Med Decis Making, 29 (2009), pp. E30-E38

[36] S. Iliffe, J. Manthorpe, A. Eden Sooner or later? Issues in the early diagnosis of dementia in general practice: a qualitative study Fam Pract, 20 (2003), pp. 376-381

[37] S. Lliffe, J. Manthorpe The hazards of early recognition of dementia: a risk assessment Aging Ment Health, 8 (2004), pp. 99-105

[38] J.D. Schaafsma, Y. van der Graaf, G.J. Rinkel, E. Buskens Decision analysis to complete diagnostic research by closing the gap between test characteristics and cost-effectiveness J Clin Epidemiol, 62 (2009), pp. 1248-1252

[39] D.W. Lee, P.J. Neumann, J.A. Rizzo Understanding the medical and nonmedical value of diagnostic testing Value Health, 13 (2010), pp. 310-314

[40] P.J. Neumann, J.T. Cohen, J.K. Hammitt, T.W. Concannon, H.R. Auerbach, C. Fang et al. Willingness-to-pay for predictive tests with no immediate treatment implications: a survey of US residents Health Econ, 21 (2012), pp. 238-251

[41] A. van Gestel, J.L. Severens, C.A. Webers, H.J. Beckers, N.M. Jansonius, J.S. Schouten Modeling complex treatment strategies: construction and validation of a discrete event simulation model for glaucoma Value Health, 13 (2010), pp. 358-367

[42] R.L. Handels, P. Aalten, C.A. Wolfs, M. Olderikkert, P. Scheltens, P.J. Visser et al. Diagnostic and economic evaluation of new biomarkers for Alzheimer's disease: the research protocol of a prospective cohort study BMC Neurol, 12 (2012), p. 72

[43] J. Hort, J.T. O'Brien, G. Gainotti, T. Pirttila, B.O. Popescu, I. Rektorova et al. EFNS guidelines for the diagnosis and management of Alzheimer's disease Eur J Neurol, 17 (2010), pp. 1236-1248

[44] D.S. Knopman, S.T. DeKosky, J.L. Cummings, H. Chui, J. Corey-Bloom, N. Relkin et al. Practice parameter: diagnosis of dementia (an evidence-based review). Report of the Quality Standards Subcommittee of the American Academy of Neurology Neurology, 56 (2001), pp. 1143-1153

[45] C. Green Modelling disease progression in Alzheimer's disease: a review of modelling methods used for cost-effectiveness analysis Pharmacoeconomics, 25 (2007), pp. 735-750 
[46] D.G. Fryback, J.R. Thornbury The efficacy of diagnostic imaging Med Decis Making, 11 (1991), pp. 88-94 


\section{APPENDIX 1. SEARCH STRATEGY PUBMED UP TO MARCH 2011}

\begin{tabular}{|c|c|}
\hline$\#$ & Search term \\
\hline \#46 & Search \#8 and \#24 and \#45 \\
\hline \#45 & Search \#27 or \#44 \\
\hline \#44 & $\begin{array}{l}\text { Search } \# 28 \text { or } \# 29 \text { or } \# 30 \text { or } \# 31 \text { or } \# 32 \text { or } \# 33 \text { or } \# 34 \text { or } \# 35 \text { or } \# 36 \text { or } \# 37 \text { or } \# 38 \text { or } \# 39 \text { or } \# 40 \text { or } \# 41 \\
\text { or } \# 42 \text { or } \# 43\end{array}$ \\
\hline \#43 & Search pharmaco-economic $*[$ Title/Abstract] \\
\hline \#42 & Search pharmacoeconomic*[Title/Abstract] \\
\hline \#41 & Search cost\$\$identificat*[Title/Abstract] \\
\hline \#40 & Search cost\$comparison $*[$ Title/Abstract] \\
\hline \#39 & Search cost\$consequence $*[$ Title/Abstract] \\
\hline \#38 & Search cost\$minimi*[Title/Abstract] \\
\hline \#37 & Search cost\$utili*[Title/Abstract] \\
\hline \#36 & Search cost\$stud*[Title/Abstract] \\
\hline \#35 & Search cost\$analy*[Title/Abstract] \\
\hline \#34 & Search cost\$sevaluation $*[$ Title/Abstract] \\
\hline \#33 & Search cost\$́benefit*[Title/Abstract] \\
\hline \#32 & Search cost\$effective $*[$ Title/Abstract] \\
\hline \#31 & Search costing[Title/Abstract] \\
\hline \#30 & Search costly[Title/Abstract] \\
\hline \#29 & Search costs[Title/Abstract] \\
\hline \#28 & Search cost[Title/Abstract] \\
\hline \#27 & Search $\# 25$ or $\# 26$ \\
\hline \#26 & Search models, economic/ \\
\hline \#25 & Search cost and cost analysis/ \\
\hline \#24 & Search \#12 or \#23 \\
\hline \#23 & Search $\# 13$ or $\# 14$ or $\# 15$ or $\# 16$ or $\# 17$ or $\# 18$ or $\# 19$ or $\# 20$ or $\# 21$ or $\# 22$ \\
\hline \#22 & Search cognitively\$impair*[Title/Abstract] \\
\hline \#21 & Search memory $\$$ disorder[Title/Abstract] \\
\hline$\# 20$ & Search MCI[Title/Abstract] \\
\hline \#19 & Search cognitive\$\$impair*[Title/Abstract] \\
\hline \#18 & Search cognitive\$disorder[Title/Abstract] \\
\hline \#17 & Search psychogeriatr $*[$ Title/Abstract] \\
\hline \#16 & Search neurodegen $*[$ Title/Abstract] \\
\hline \#15 & Search cognitive\$dysfunct $*[$ Title/Abstract] \\
\hline \#14 & Search dement $*$ [Title/Abstract] \\
\hline \#13 & Search alzheimer*[Title/Abstract] \\
\hline \#12 & Search \#9 or \#10 or \#11 \\
\hline \#11 & Search neurodegenerative diseases/ \\
\hline$\# 10$ & Search dementia/ \\
\hline \#9 & Search alzheimer's disease/ \\
\hline \#8 & Search \#6 or \#7 \\
\hline \#7 & Search diagnos*[Title/Abstract] \\
\hline \#6 & Search \#1 or \#2 or \#3 or \#4 or \#5 \\
\hline \#5 & Search discriminant analysis/ \\
\hline \#4 & Search predictive value of tests/ \\
\hline \#3 & Search diagnosis, differential/ \\
\hline \#2 & Search sensitivity and specificity/ \\
\hline \#1 & Search diagnosis/ \\
\hline
\end{tabular}




\section{APPENDIX 2. SEARCH STRATEGY NATIONAL INSTITUTE FOR HEALTH RESEARCH ECONOMIC EVALUATION DATABASE UP TO MARCH 2011}

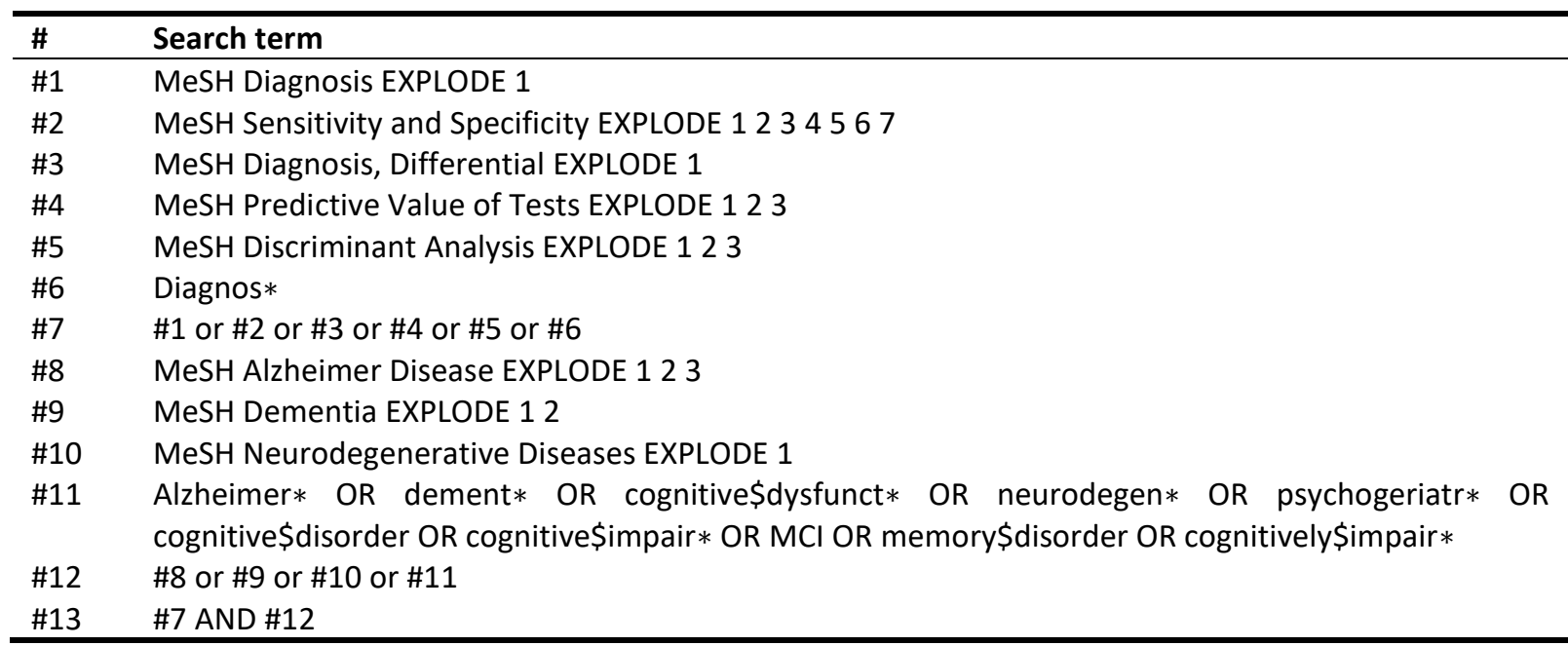

Abbreviation: MeSH, Medical Subject Headings.

* the wildcard character 